УДК 821.163.41.09:398

821.163.2:398

https://doi.org/10.18485/godisnjak.2016.11.11

Вера П. Ваш*

Ваљевска гимназија

Ваљево
Оригинални научни рад

Примљен: 05. 10. 2016.

Прихваћен: 20. 10. 2016.

\title{
ЈУНАЦИ СРПСКЕ УСМЕНЕ ПОЕЗИЈЕ О КОСОВСКОМ БОЈУ У БУГАРСКОЈ УСМЕНОЈ ТРАДИЦИЈИ - КОМПАРАТИВНА АНАЛИЗА
}

С обзиром на то да су Срби и Бугари у средњем веку имали Турке за заједничког непријатеља и на скоро идентичан начин трпели последице важних историјских догађаја у свом окружењу, не чуди што је поетика косовског мита српске усмене традиције нашла своје уточиште и у бугарској епици. Мотиви елементарних наративних модела у бугарској епској традицији су, или преузети из српског корпуса косовских мотива, или су актанти неких старијих религијских, фолклорних или књижевних модела. Кад је модел Косовског боја у питању, преузимања могу варирати од копија, преко препева, до варијаната.

У овом раду ћемо се задржати на ликовима који су у највећој мери сачували свој идентитет у бугарским варијантама или су одступања од иницијалног модела фрагментарна. То су кнез Лазар, кнегиња Милица, Вук Бранковић, Југовићи, Косанчић Иван, Топлица Милан и Мусић Стеван ( Васојевић Стево).

Кључне речи: Косовски бој, јунак, епска поезија, бугарски, варијанте, одступања, иницијални модел.

*vasveravas@gmail.com 
Ширењу, сељењу и преузимању мотива о Косовском боју погодовао је универзални мотив пропасти царства као нека врста елементарне митске матрице која је, природно, повезивала судбине народа у најближем окружењу, превасходно српског, бугарског и македонског. Дубина и трајност историјских веза међу народима балканских земаља је последица јединственог етнокултурног простора: „Управо усмена традиција, оличена у епским песмама и историјским предањима о заједничким балканским јунацима и догађајима, представља духовни мост међу људима, народима и језицима, нипошто границу која их дели по етничким линијама” (Сувајџић 2010: 348). Дакле, историјска матрица је само основа за ширење мотивске грађе у зависности од националних, временских и просторних корелата у којима песма настаје. Веза између мотива епске творевине и његове историјске одреднице је, ипак, веома лабава. Мотив прихватаға иарства небеског је идејна срж косовске теме који се у нашој усменој традицији обично доживљава као митема ${ }^{1}$ за страдалништво кнеза Лазара, иако знамо да тај мотив, у средњем веку, постоји и код осталих европских народа.

Читав круг песама косовске легенде почива на три основна динамичка мотива: мотиву издаје (Вук Бранковић), мотиву погибије владара (кнез Лазар) и мотиву херојства неустрашивог јунака (Милош Обилић). Све остале мотиве који обликују ова три основна на каузалном нивоу (бројност Турака, пророчански сан кнегиње Милице, кнежева вечера, здравица, оклеветани јунак, ухођење непријатеља) можемо сврстати у статичке, док оне који логички нису есенцијални или битни за остварење динамичких мотива сврставамо у слободне, невезане мотиве (Муратово писмо Лазару, кнежева клетва, свађа Лазарових кћери, причешћивање јунака, закаснели јунак, смрт мајке...). Посебну врсту мотива представљају они мотиви који су етимолошки и логички тешко објашњиви, али чија је сврсисходност прихваћена као непроменљиви код јер без њих, косовска епопеја не би била оно што јесте. Најупечатљивији пример за ову врсту мотива је мотив опредељеља за небеско ияарство са којим се, по значају, не може упоредити ни један други. Можемо навести и пример из Кнежеве вечере (Караџић 1977: 196) где кнез Лазар без икакве наратолошке условљености наздравља Вуку Бранковићу као „невјери”. Срета Стојковић у својој Лазарици тај детаљ дефинише као „Лазареву карактерну црту поводљивости која је и довела до оног изненадног и чудног догађаја приликом косовске вечере у очи Видова дана" (Стојковић 1906: VII).

„Прве варијанте епских песама и предања о Косовском боју на бугарском и македонском терену забележене су крајем 19. века" (Сувајџић

\footnotetext{
${ }^{1}$ Основна конститутивна јединица мита (прим. аут; в. у Литература: Строс 1977).
} 
2012a: 134). Зачудно мали број песама са тематиком Косовског боја у македонској усменој традицији може се објаснити историјском повезаношћу бугарског и македонског народа у дужем временском периоду, па су многе песме, настале и забележене на тлу данашње Македоније, штампане у бугарским зборницима као бугарске, иако је наведено њихово географско порекло.

Ако прихватимо закључак С. Самарџије, изведен на основу теза Е. М. Мелетинског и А. Веселовског наведених у Поетици мита, тј. Историјској поетици, који гласи: „Сви битни заплети на којима почивају епске судбине, суштински представљају одавно испричане митске приче, само што су, подвргнуте захтевима поетичког система, добиле нови смисао," (Самарџија 2008: 25) - онда не би било тешко објаснити настанак сличних, чак и истих сижејних матрица у епској структури усменог стваралаштва код историјски, просторно, културно и религијски разнородних етничких заједница, а камоли блиских народа какви су бугарски и српски. Отуда не чуди што је поетика косовског мита српске усмене традиције нашла своје уточиште и у бугарској епици, било да су мотиви преузимани, препевавани, допевавани или мењани у складу са историјско-етичким потребама бугарске традиције. Додајмо да су честа копирања и у домену стила и израза, реторичких фигура, устаљених бројева, дескриптивних елемената... Иако је природно да се мотивационе формуле које граде одређене ликове у песмама о Косовском боју врло мало мењају, постоје и они мотиви који су претрпели знатне промене. Оно што не може остати непримећено, то је да се неки мотиви који карактеришу одређене ликове српске косовске епопеје до те мере деформишу у новим условима да долази скоро до потпуне измене гномског кода који их је у српским варијантама афирмисао као носиоце одређене формуле. Најизразитији и најдрастичнији пример је епски лик Милоша Обилића, чија се акомодација у новим условима развила скоро до непрепознатљивости и напуштања иницијалног модела створеног у српској епској традицији.

У даљем тексту ћемо се задржати на ликовима српске усмене поезије о Косовском боју који су у највећој мери сачували свој идентитет у бугарским варијантама и анализи разлика и одступања од иницијалног модела.

\section{Кнез Лазар и кнегиња Милица}

Писмо које кнез Лазар добија пре боја има улогу перформатива којим се извештава о надмоћи, сили и бројности турске војске, али истовремено се наговештава и пропаст царства. У бугарској варијанти 
косовске лазарице Цар Лазар, султан Мурад, Милош Кобиличин и Юже Бранкович в Косовския бой (СбНУ 2008: 43/113), цару Лазару соко доноси писмо у коме стихови који апострофирају небројивост турске војске касније добијају конотативну функцију оправдања за пораз: „У книга ce, либе, показува,/ турска войска ни край, ни брой нема!” Ултиматум султана Мурата о признавању његове врховне власти и позиву на мегдан на Косово покретачки је мотив песме Бой на Косово поле (СбНУ 2008: 3). У обе варијанте, предсказује се пропаст царства. Међутим, у бугарском препеву нема клетве Лазарове и чини се да је у првом делу песме, пре одласка у бој, пренаглашен један мелодрамски, скоро лирски детаљ - жалост Лазарова што ће млада Милица постати турска робиња. Ако се томе дода и његово често обраћање Милици са „либе”, онда је видљива тежња бугарског певача да Лазару придода нешто од особина обичног смртника који се не стиди своје љубави према жени, чиме се не умањује његов витешки и владарски лик.

Снощи вечер било на вечера, като седна срьбски ми цар Лазар, като седна вечер да вечера и при него Милица кралица. На вечера соколе пристигна и паднало цару на колена, протьрсило тия бели крила, изтьрсило едно бело писмо.

- Фала тебе, Милице кралице, нали питаш, право да ти кажем: у писмо се, либе, показува, наша земя турци че притисна, наше царство турци че презема, сичка войска наша че изгине и я-зе чем, либе, да погинем; а тебека млада че зароба, тизе че си у турци робиня. У книга се, либе, показува, турска войска ни край, ни брой нема!² (Вакарелски 1961)

У српском оригиналу, писмо шаље цар Мурат позивајући га у бој уколико не пристане на његове услове: „Већ ми пошљи кључе и хараче,/ златне кључе од свијех градова,/ и хараче од седам година” (Караџић 1977:

\footnotetext{
${ }^{2}$ Българско народно творчество в дванадесет тома. Т. III/23 Исторически песни. Съст. Христо Вакарелски. София, 1961.
} 
195). И у дужој варијанти песме која је записана после Вука, а сачувана у рукопису Дене Дебељковића (в. Петровић 2001: 269), писмо шаље цар Мурат са нешто умањеним захтевима, али и у једној и у другој варијанти кнез Лазар „Књигу гледа, грозне сузе рони”, тј. „Књигу гледа и сузе ми лије," као што и обе варијанте имају наставак са епском формулом клетве. Код Вука је то засебна песма од шест стихова у којој клетву изговара кнез, а у верзији попа Дебељковића је Милица госпођа ,много паметљива” те она сугерише кнезу страшнију клетву којом треба позвати српску властелу у бој: „Куј не дође на бој на Косово,/ Из руке му жито не родило, / Нит му у кућу дете проплакало" (Петровић 2001: 177). Први део песме Султан Мурат пише књигу кнезу Лазару, коју под бројем III објављује Стојан Новаковић у својој књизи, истоветан је Вуковој варијанти, али се у наставку, у коме је такође доминантан мотив клетве, издвајају стихови: „Ко је Србин и српскога рода,/ И од српске крви и кољена,/ А не дош'о на бој на Косово...” (Новаковић 1906: 38). Овакви стихови епској формули владара који дан касније херојски гине на бојишту, обезбеђују улогу мученика за свој народ, али с обзиром да „варијанта писања књига јесте стереотипна уводна формула која омогућава развој радње" (Петровић 2001: 243), ови стихови омогућују структури косовског мита развој радње у оном правцу у коме је митопоетика косовске легенде нама данас и позната. У даљем току бугарске варијанте, издвојило се неколико мотива које срећемо појединачно и у изворним варијантама:

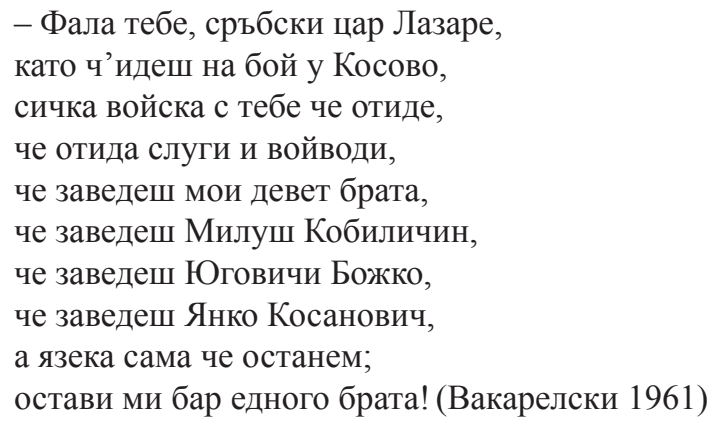

Милица, захваљујући се, тражи од цара Лазара да јој пре одласка у бој остави бар једнога брата да не остане сама. У епском каталогу јунака, Янко Косанович кореспондира са Војином Југовићем из Вукове Цар Лазар и ияарица Милица, с тим што је у бугарском препеву Янко Косанович сурово одгурнуо Милицу када га је заустављала хватајући узде његовог коња: „Разсьрди се Янко Косанович,/ рипна с коньо, с коньо я прегази.” 
У Вуковој варијанти (као и код Стојана Новаковића), народни певач je, употребивши епитет у комбинацији са антономазијом, остварио снажан и леп троп, што није претерано честа појава у нашем епском усменом песништву: „Цар-Лазаре, српска круно златна” (Караџић 1977: 182). „Епска 'царица' Милица никада није у средишту радње, али учествује у обликовању догађаја" (Самарџија 2008: 221). У Вуковој варијанти, њен захтев за братом од заклетве је оправданији: „да ти може књигу однијети / у Косово и натраг вратити" (Караџић 1977: 182). У Новаковићевој збирци Косово, српске народне песме о боју на Косову, песма са овим мотивом носи назив Царииа Милица тражи од изара Лазара да јој остави једног брата у Крушевиу и завршава се сустизањем војске од стране слуге Голубана на путу до Косова.

При крају песме Цар Лазар, султан Мурад, Милош Кобиличин и Юже Бранкович в Косовския бой, два сокола доносе царици Милици писмо са вешћу о погибији оба владара, српског и турског. Трагичну вест потврђује и управо пристигао из боја, слуга Гълабина, смртно рањен, коме се царица Милица обраћа са непознан юначе, што упућује на недоследност певача с обзиром да је то царев слуга који ју је, онемоћалу, на дан одласка војске на Косово, по наредби цара Лазара, унео у двор. Сижејни ток песме је пак, на крају, доследно спроведен. Наиме, страх кнеза Лазара да ће после изгубљене битке, његова љуба постати турска робиња, слуга Голубан покушава да реши саветом царици Милици да се преруши:

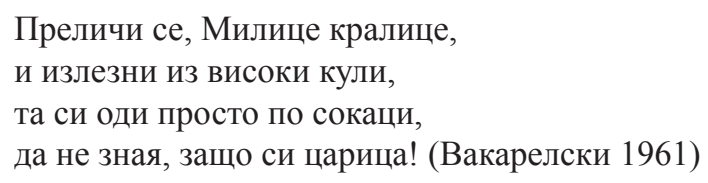

У Вуковој Цар Лазар и царицุа Милица (Караџић 1977: 182) вест доносе два врана гаврана, а потврђује рањени слуга Милутин. У симболичкој равни, одабир птица за веснике лоших вести може упућивати на однос певача према лику кнеза Лазара, уколико прихватимо тезу да је у бугарским варијантама, осим препевавања, било и оригиналних подухвата. Наиме, соко претпоставља владарску, вишу класу, елиту, самим тим и акценат на погибији цара, а гавран, птица злослутница, вије се тамо где је много крви, те апострофира народ и пропаст царства који ће уследити после Лазарове жртве.

У бугарској лазарици, кнеза Лазара на Косову убија црни Арапин. Пре тога, Милош је извршио свој подвиг, побугарчио и убио султана, те страдао од Турака. Чини се да његова погибија погубно делује на српску војску, јер убрзо гине и сам кнез Лазар. 
Заигра се един църн арапин, та погуби сръбски ми цар Лазар; заигра се Юговичи Божко, та погуби църна арапина; (Валарелски 1961)

Зидање задужбине пре боја је формула коју срећемо код Бугара у песми Изграждане на Дечанския манастир (СбНУ 2008: 43/261) која корелира са изворним песмама Зидање Раванице (Караџић 1977: 126-128) и Опет зидање Раванице (Караџић 1977: 129-134) и Кнез Лазар зида себи задужбину (Новаковић 1906: 25-29). Б. Сувајџић примећује да је у бугарској песми уочљиво „интензивирање религиозно - хришћанских елемената косовског предања. На интервенцију Св. Илије, цар Лазар започиње изградњу Дечанског манастира, како би постао небески цар.[...] Песма је настала контаминацијом два изворно косовска мотива: изградње цркве, духовног тестамента кнежевог, и мотива одабира царства" (Сувајџић 2012а: 148). У српским варијантама, разлози су профане природе: у првој је то предлог кнегиње Милице која подсећа Лазара на традицију немањићског задужбинарства, а у другој кнез Лазар, можда и неочекивано, испољава црту непримерене гордости: „нек се сјаје, нек се моје знаје!” (Караџић 1977: 130).

У бугарској песми, напротив, кнез Лазар је великодушни владар који мисли на свој народ и поданике који учествују у градњи манастира:

- Хей, фала ти, Юже Бранковиче, като ойдеш у равно Дечинье, да събереш сичка сиротиня; секому че двойно да заплащаш, че им плащаш дванаесе гроша, на дулгере по дваесе и пет, да ги служиш вечер руйно вино. (Вакарелски 1961)

Када се испостави да је Юже (Вук) Бранковић непоштено присвајао царево благо намењено градњи, Лазар га препушта Божјем суду, надокнадивши свим мајсторима оно што им је закинуто. Тај детаљ је још један прилог тези Б. Сувајџића о наглашеним религиозно-хришћанским елементима у овој песми, али и пружа ново светло на епски лик кнеза Лазара:

- Хей, фала ти, Миал, млад дулгерин, ти нали си калето доградил и нали си манастир доградил, ако не е право изплащано, има тамо който да го съди, 
сам че Господ него да го съди.

Тогай окна сръбски ми цар Лазар, тогай събра сичка сиротиня, че кои са калето градили и кои са манастир градили, що имаше у царо иманье, сичкото им иманье раздаде. (Вакарелски 1961)

Сан као епска формула предсказања често је коришћен мотив у усменој традицији. У песми Сънът на Милица кралица I (СбНУ 2008: 43/114-115), уз извесна одступања, спојено је више мотива који се могу пратити и у осталим бугарским песмама са темом Косова. У овој варијанти, најмлађи брат је Голубин и он, после обећања да ће му цар царство поклонити, пристаје да остане на двору са сестром. Одступања од извора се тичу и обећања Бошка Југовића, датог сестри, да ће султану везати ноге са вратом и убити га, што је и урадио. Посебно занимљива градација остварена је у сликама крвавих косовских јунака које среће најмлађи брат Голубин, у покушају да провери сестрин сан (кнез Лазар до колена, Јанко до појаса, Бошко до рамена). Кнежева клетва, позната у више варијаната, употребљена је и овде, у сижејном контексту сна:

Кой не додив бой да помогне, толпо сие живо наодило, на нива семе му не ницало, у ягъл му овце не блеяло, в убор му кравине ревали, у яхър му конине вищали, у кукя му дите не викало, у скулена огне не плакало. (СбНУ 2008: 43/114-115)

Мотив краљичиног сна се појављује и у варијантама предсказања пропасти бугарског царства за време цара Ивана Шишмана, као и у песмама са темом његове погибије (Погинване на цุар Иван Шишман).

\section{Вук Бранковић}

Нејасно мотивисане противуречности између ликова Вука Бранковића и Милоша Обилића „на чијем сукобу почивају мотивска чворишта косовске легенде” (Сувајџић 2012а: 135) условиле су да негативна конотација лајтмотива косовског пораза - Вукова издаја, у бугарском усменом песништву добије и своју предисторију у песми Изграждане на Дечанския манастир (СбНУ 2008: 43/261). Епски каталог задужбина, оригинална 
особеност српске усмене епике, у бугарским народним песмама није од значаја. И у бугарској, и у српским варијантама, зидање цркве се завршава пре задатог рока јер поштени неимари (Раде, односно дулгерин Миајло) журе да би зауставили непоштене настојнике градње. Улогу Југовића и Југ Богдана из српских, преузима Вук (Юже) Бранковић у бугарској верзији и закидањем цареве наднице мајсторима и раји, „обезбеђује” себи статус омраженог јунака који ће га пратити у бугарским прерадама изворних мотива:

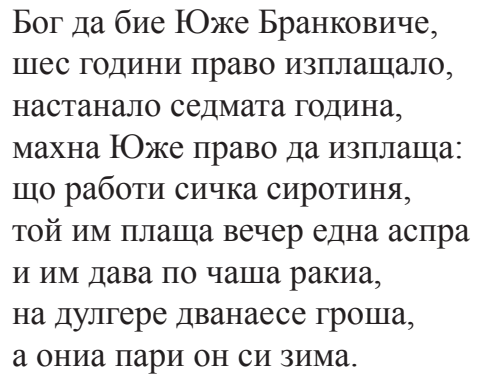

За разлику од Милоша Обилића који у новим условима успева да се удаљи од свог основног митопоетичког кода лажно оптуженог, неустрашивог јунака који остварује свој завет и убија Мурата (чак обећава и извршава и виши циљ свог супротстављања Турцима - сланином бугарчи, тј. христијанизује Турчина), Вук Бранковић, уз незнатна одступања следи задату му улогу издајника. У већ поменутој лазарици Цар Лазар, султан Мурад, Милош Кобиличин и ЮжеБранкович в Косовския бой (СбНУ 2008: 43/113), Юже Бранкович није издајник само у боју, него и пре боја. Он одлази у турски табор да извести султана о доласку Милоша Обилића и предлаже Мурату да понизи Милоша тражећи да га, уместо у руку, пољуби у чизму: „тизе немой рька да си дадеш,/ на си подай твоя десна чижма/ да цалива Милош Кобиличин,/ да се знае, че са долни от нас!”. Негативни контекст Вукове издаје доведен је до врхунца улогом крвника према својим најближима:

Заигра се Юже Бранковиче, тий не знали защо е измама, че че оно и них да погуби, като махна сабля димиския, та погуби Юговичи Божко и погуби Янко Косанович, и погуби Иван, свой побратим. (СбНУ 2008: 43/113) 
Југовићи

Југовићи се у бугарским варијантама, као и у изворним, везују за кнеза Лазара и сестру им, кнегињу Милицу. Није им, као у српској усменој традицији, намењена улога грамзивих настојника који координирају градњом Лазарове задужбине и присвајају и обогаћују се на туђ рачун (Onет зидање Раванице, Караџић 1977: 129-134). Углавном су одана браћа којима су витешки дух и служба отаџбини изнад сваке личне или породичне љубави. Зато ће се у више наврата варирати та врста хероизма приликом њиховог одговора на сестрину молбу да пред бој, бар један остане на двору:

Иди, сестро, у двори на кули, язе нечем назад да се върнем, я че д’ идем на бой у Косово, бой че бием за милого Бога, кръв че ляем за ристянски народ! (СбНУ 43/113)

О достојанственом и храбром држању у боју и страдању Југ Богдана и деветорице синова сведоче истоветни стихови у Пропасти ицарства сpnскога (Караџић 1977: 188) и у песми Косовски бој (Новаковић 1906: 55):

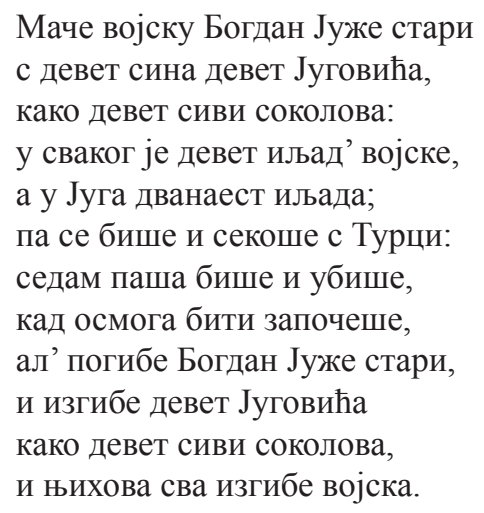

Разлози због којих долази до измена у бугарским варијанатама у односу на српску косовску епику, могу бити различити, некад чак и тешко објашњиви, осим претпоставке да су профани елементи услед своје волшебности, сачувани и у усменој традицији. Такав је случај са песмом Майка и убитият й син (СбНУ 2008: 44/101) у којој се појављује мотив бездушне мајке, који се код Бугара назива мотивом „коравосьрдечната майка" (мајка крвница) што и није сасвим адекватно чину њеног бездушја. 
Наиме, мајка са мртвог сина на бојишту скида злато којим плаћа слугу који ће бринути о њој.

Гарваница потиом говори:

- Не грькам ти Дамян да прокуба, на ти грькам, за Дамян да кажа:

загинал е у Косово полье!

Пуста майкя, каменно ю сръце ни завика, ни слъзи порони,

Па заврати скути до поясе и заврати раце до рамена, па нагази кръви до колена, та превръна три иляди глави, доде найде Дамянова глава.

Па му бръкна у десна подплата, та извади три кемере злато, па се майкя назад поврьнала, па уцани ратай да я слуша седем годин за седем кесии (СбНУ 44/101).

И варијанта број 90 чува овај пример суровог одступања од извора за који Б. Сувајџић каже да је ,усамљени пример драстичног извинућа изворног мотива у бугарској фолклорној традицији, као у пројекцији искривљених огледала" (Сувајџић 2012а: 135), док је варијанта број 88 скоро идентична српском оригиналу за који Вук наводи да је „из Хрватске”, а претпоставка историчара књижевности, додуше непотврђена, јесте да је Вук ову песму добио од Лукијана Мушицког. Иако се лик мајке Југовића везује за косовску епику, ипак, према С. Петровић (2011: 251) „ова песма није чврсто интегрисана у корпус косовске традиције."

\section{Косанчић Иван и Топлица Милан}

Обојица јунака у бугарским варијантама задржавају улоге побратима Милоша Обилића које им је наменила српска епика. Некад су им измењена имена: Кусаче Иван (СбНУ 2008: 3) или Јанко Косанович (СбНУ 2008: 43), тј. Милен от Топлица (СбНУ 2008: 43), или је Јанку Косановичу намењена улога најмлађег брата царице Елене који неће да прекрши заклетву дату цару и остане са њом на двору (СбНУ 2008: 43/113). Код Бугара Кусаче Иван уходи турску војску (а не Милош) и доноси Милошу вест да је издајника Вьлчо Бранковича ненадано затекао на договору са 
султаном Муратом (СбНУ 2008: 3). Њих је, на превару, убио управо Юже Бранкович (СбНУ 2008: 43/113), а на бојишту, слуга Голубан проналази мртвог Јанка Косановича (СбНУ 2008: 43/114). У другој варијанти (СбНУ 2008: 3) и њих, и кнеза Лазара, и остале српске војсковође, по крвавим калпацима препознаје слуга Првузор који ускоро и сам гине од сабље Юже Бранковича.

Занимљиво је да овој двојици јунака није намењена улога дародаваца који, уз Милоша Обилића, на поласку у бој заклињу Косовку девојку да чува успомену на њих, јер у бугарској варијанти девојка нема, као код Вука, улогу видарице која лечи рањене јунаке и жали за њима тражећи ова три јунака међу изгинулима.

\section{Васојевић Стево}

Васојевић Стево је лик који припада моделима песама са епском формулом закаснелог јунака. Најобимнију верзију од 395 стихова објавио је Јован Стејић (Сабор истине и науке, Београд, 1832), нешто краћа је верзија у зборнику Стојана Новаковића, а улогу закаснелог јунака Вук намењује Мусић Стевану (Караџић 1977: 188). Бугарска верзија спаја мотиве, ликове и сижее све ове три варијанте. У песми Васоевик Стево на Косово 3 записаној у Брезнику, нема продуженог увода у коме се преко љубе Стеве Васојевића апострофира формула сна као предсказања погибије, као ни молбе сестре да одустане од одласка на Косово. Те устаљене епске формуле су појачане мотивом жене и мајке са чедом у наручју што силовито подсећа на антички модел дат у дијалогу Хектора и Андромахе из Илијаде. Исто тако, нема слутње смрти изречене у оригиналној варијанти кроз форму сентенце: „Добро мисли и упамти, селе,/ па погледај бијелу западу:/ Кад се роди од запада сунце,/Онда ћу ти из Косова доћи!” (Петровић 2001: 137). Зато је део описа сусрета са Косовком девојком на реци Ситници и осакаћеним Павлом Орловићем на бојишту - скоро доследно идентичан оригиналу. При крају бугарске варијанте настају одступања. Цар Лазар је још жив и заклиње Стевана да настави бој са Турцима (СбНУ 2008: 43/272):

- Цар Лазаре, верна круно златна, опрости ми, що не съм достигал сас мойега слуга Воистина. А цара му нищо не говори.

${ }^{3}$ Българско народно творчество в дванадесет тома. Т. ІІІ. Исторически песни. Съст. Христо Вакарелски, София, 1961. 
Стево слезе от коня крилата, па му сака рука да му люби.

А царо му потио говори:

- Драг юначе, Васоевик Стево, да си спремиш коня крилатога

и да викаш Вуковике Бранка

да идете на бой у Косово,

та сас Бранка турци да юрите!

Стево скочи на ноге юнашки, укачи се на коня крилата

и сас ньега слуга Воистина

и сас ньега Вуковике Бранко.

На Косово коньи нагонише

и сас коньи турци нагонише.

И тогай се умири Сърбия.

Дакле, у свести народног певача, чак и у Бугарској, јесте да се борба мора наставити и да једино тако жртва кнеза Лазара има смисла. Према тумачењу А. Колеве (2011: 536), завршетак ове песме је неочекивано оптимистичан јер Стево растерује Турке са Косова и „умирује Србију”.

Песме о Косовском боју у српској народној традицији суштински јесу песме о пропасти српског царства. Аналогно њима, у бугарској епској и историјској традицији пратимо песме о пропасти бугарског царства. Стога не чуди мешање и укрштање мотива, препевавање, као ни преузимање ликова и сижеа уз већа или мања одступања. Анализирајући формулативност етимолошке фигуре град градила, Б. Сувајџић истиче да „интернационални мотивски слој провоцира памћење традиције у формулама" (Сувајџић 2012б: 13). Сматрамо да се ова тврдња у целости може применити и на мотиве косовске тематике у компаративној анализи српских и бугарских варирања ове теме. 


\section{ИЗВОРИ И ЛИТЕРАТУРА}

\section{Публикација доступна оn-line:}

Ангелов, Вакарелски 2005: Б. Ангелов, Х. Вакарелски, Сенки из невиделица, Книга на българската народна балада, под редакцията на Тодор Моллов 11. 01. 2005. http://liternet.bg 25. - 30. 01. 2016.

Миладинов, Миладинов 2007: Д. Миладинови, К. Миладинов, Български народни песни, под редакцията на Тодор Моллов 21. 07. 2007. http://liternet.bg 25. - 30. 01. 2016.

Вакарелски 1961: Х. Вакарелски, Българско народно творчество в дванадесет тома / III/ Исторически песни, редакцията на Т. Моллов 01.07.2006. http://liternet.bg 29. 01. 2016.

Шапкарев 2008: К. Шапкарев, Сборник от български народни умотворения/ I/Песни, под редакцията на Тодор Моллов 19. 02. 2008. http:// liternet.bg 25. - 30.01. 2016.

Цонев 2006: Б. Цонев, Родна китка: Отбор народни песни, под редакцията на Тодор Моллов 07. 03. 2006. http://liternet.bg 25. - 30. 01. 2016.

Ангелов, Вакарелски 2006: Б. Ангелов, Х. Вакарелски, Трем на българската народна историческа епика/ От Момчила и Крали Марка до Караджата и Хаджи Димитра, под редакцията на Тодор Моллов 04. 08. 2006. http://liternet.bg 25. - 30. 01.2016

Арнаудов 2007: М. Арнаудов, Български народни песни/ II/ Епос, под редакцията на Тодор Моллов 21. 10. 2007. http://liternet.bg 25. - 30. 01. 2016.

Новаковић 2011: С. Новаковић, Косово: српске народне песме о боју на Косову (S II 2351) 11. издање, Београд, 1906. http://digitalna.nb.rs/sf/ NBS/Stara_i_retka_knjiga 31.01.2016.

Novaković, Stojan: Kosovo, srpske narodne pesme o boju na Kosovu, 10. izdanje, Zagreb. (Digitized by the Internet Archive in 2011. University of Toronto) http://www.archive.org/details/kosovosrpskenar00nova/ 31. 01. 2016.

Витезица 1937: В. Витезица, Антологија народне поезије I, Београд: ИКП „Геца Кон”. CK3.

Ђурић 1988: В. Ђурић, Антологија народних јуначких песама, Београд:

Караџић 1975: В. С. Караџић, Српске народне пјесме I, Београд: Просвета.

Караџић 1977: В. С. Караџић, Српске народне пјесме II, Београд: Нолит. 
Новаковић 1906: С. Новаковић, Косово, српске народне песме о боју на Косову (11. издање), Београд: Панпублик (библ. Корени), 1988. (по издању из 1906).

Стојковић 1906: С. Ј. Стојковић, Лазарица или Бој на Косову (народна епопеја у 24 песме), Београд: СКЗ

Ђорђевић 1990: Н. Милошевић Ђорђевић, Косовска епика, Београд: ЗУНС.

Иванова 1992: Р. Иванова, Епос, обред, мит, Софија. http://search.library. utoronto.ca 26. 01.2016.

Карановић 2010: 3. Карановић, Небеска невеста, Београд: Друштво за српски језик и књижевност Србије.

Кметова 1991: Т. Кметова, Косовски бој и Косово поље у бугарском јуначком епу, у: Научни састанак слависта у Вукове дане, 19/1, Београд: МСЦ, 503-510.

Колева 1991: А. А. Колева, Косовски јунаци у бугарској народној епској песми, у: Научни састанак слависта у Вукове дане, 19/1, Београд: МСЦ, 533-540.

Лома 2002: А. Лома, Пракосово (Словенски и индоевропски корени сриске епике), Београд: САНУ (Балканолошки институт, посебна издања, 78)

Љубинковић 2010: Н. Љубинковић, Трагања и одговори (Студије из народне књижевности и фолклора I) Библиотека Српско усмено стваралаштво, књ. 5 (ур. С. Самарџија), Београд: Институт за књижевност и уметност.

Љубинковић 2006: Н. Љубинковић, Митско ткиво - један од конститутивних елемената епске легенде јужних Словена - легенда о Косовском боју, легенда о Марку Краљевићу, у: Митолошки зборник 1-2; (1998-2000. ур. М. Стојановић) Рача - Београд: Центар за митолошке студије Србије. https://www.academia.edu 17. 01. 2016.

Мелетински 2009: Ј. М. Мелетински, Увод у историјску поетику епа и романа, Београд: СКЗ.

Михаљчић 1984: Р. Михаљчић, Лазар Хребељановић, Београд: Нолит.

Михаљчић 2001: Р. Михаљчић, Сабрана дела (књ. III): Јунации косовске легенде, Београд: Српска школска књига, Knowledge.

Петровић 2001: С. Петровић: Косовска епика у усменој поезији, Београд: Гутембергова галаксија.

Петровић 2010: С. Петровић, Од камена ником ни камена-структурни модели песама о зидағу Раванице, Филолошки факултет Универзитета у Београду. https://www.academia.edu 9. 03. 2016. 
Петровић 2011: С. Петровић, Смрт Мајке Југовића - варијанте, рецепција и могућности тумачења, у: Жива реч, Зборник у част проф. др Наде Милошевић Ђорђевић, Београд: САНУ, Филолошки факултет, 435-478. https://www.academia.edu 15. 03. 2016.

Ређеп 2007: J. Ређеп, Косовска легенда, II издање, Нови Сад: Прометеј.

Самарџија 2008: С. Самарџија, Биографије епских јунака, Београд: Друштво за српски језик и књижевност Србије.

Српска фантастика 1989: књ. XLIV/9 (зборник, ур. П. Палавестра), Београд: САНУ.

Строс 1977: C. L. Strauss, Struktura mitova u Strukturalna antropologija (prev. Anđelko Habazin) Zagreb: Stvarnost, 213-239.

Сувајџић 1998: Б. Сувајџић, Рецепција косовског предања у бугарској фолклорној традицији, у: Српски језик, бр. 3/1-2, год. III, Београд, 491-515.

Сувајџић 2005: Б. Сувајџић, Јунаџии и маске, Београд: Друштво за српски језик и књижевност Србије.

Сувајџић 2010: Б. Сувајџић, Епска песма и историјско предање, у: Прилози језичком и књижевном образовању (зборник), Београд: Друштво за српски језик и књижевност Србије, 337-348.

Сувајџић 2012а: Б. Сувајџић, Српско и бугарско усмено стваралаштво у интеркултурном коду, у: Српско усмено стваралаштво у интеркултурном коду (ур. Б. Сувајџић), Београд: Институт за књижевност и уметност, $128-187$.

Сувајџић 2012б: Б. Сувајџић, Дновиде воде, Нови Сад/ Београд: Orpheus/ Филолошки факултет. 
Vera P. Vaš

\section{THE HEROES OF SERBIAN ORAL POETRY ABOUT KOSOVO BATTLE IN BULGARIAN ORAL TRADITION - COMPARATIVE ANALYSIS}

\section{Summary}

Given the fact that the Serbs and the Bulgarians both had the Turks as their common enemy in the middle ages, they suffered the consequences of major historical happenings in their vicinity in a similar way. Because of this it is not surprising that the poetics of Kosovo mythology found its way into Bulgarian epics. The motives of basic narrative models in Bulgarian epic tradition were either borrowed from the corpus of Serbian Kosovo mythology or they were the manifestations of some older religious, folklore or literary models. When we talk about the model of Kosove battle, the process of borrowing may vary from copies to poetic translations and different versions.

This paper focuses on characters who have mostly maintained their characteristics in Bulgarian versions or whose changes in comparison to the original model are only partial. These characters are prince Lazar, princess Milica, Vuk Brankovic, Jugovici, Kosancic Ivan, Toplica Milan and Music Stevan.

Key words: Kosovo battle, hero, epic poetry, Bulgarian, varieties, changes, original model. 